\title{
FASTEST FISH SHAPES AND OPTIMAL SUPERCAVITATING AND HYPERSONIC BODIES OF REVOLUTION
}

\author{
I. Nesteruk ${ }^{*}$ \\ Institute of Hydromechanics, NAS of Ukraine, Kyiv, Ukraine \\ Igor Sikorsky Kyiv Polytechnic Institute, Kyiv, Ukraine \\ *Corresponding author: inesteruk@yahoo.com \\ Received 18 September 2020; Accepted 21 October 2020
}

\begin{abstract}
Background. The best swimmers have a streamlined shape that provides a flow pattern without boundary layer separation and delays the laminar-to-turbulent transition. Their shape itself could be the reason of small drag and high locomotion velocity. The fastest fish, e.g., sailfish, swordfish, black marlin, etc. have another feature of their shape - a very sharp nose - rostrum, the purpose of which remains unclear. Popular belief that the rostrum is used by these predators to pierce their prey is often disputed.

Objective. In this study, we analyze the hydrodynamic aspects of the rostrum presence and the possible use of similar hulls for supercavitating underwater vehicles and fast penetration into water. We illustrate that shapes with the very sharp nose could be useful for hypersonic motion in order to eliminate overheating of the vehicle fuselage.
\end{abstract}

Methods. We use the known exact solutions of the Euler equations for the incompressible fluid to simulate the pressure distribution on the bodies of revolution with a sharp nose. The slender body theory is used to simulate the supercavitation and the axisymmetric air flows at high Mach numbers.

Results. Bodies of revolution with a rostrum similar to trunks of the fastest fish (sailfish, swordfish, black marlin) and corresponding pressure ant temperature coefficients were calculated. The proposed shapes ensure no stagnation points and no high pressures and temperatures on their noses at sub- and supersonic speeds both in water and air. The drag on such bodies of revolution was estimated for attached, supercavitating and supersonic flow patterns.

Conclusions. A method of calculation of axisymmetric bodies without stagnation points on their surface was proposed. This peculiarity of the shape allows diminishing the maximum pressure and temperature on the nose without a significant increase in drag. Such shapes with the sharp concave nose could be recommended for high-speed attached and supercavitating bodies of revolution and for the hypersonic motion.

Keywords: water animal locomotion; bodies of revolution; load reduction; drag reduction; shape optimization; unseparated shapes; supercavitation; hypersonic flows.

\section{Introduction}

The high swimming speed of aquatic animals continues to draw attention to the shape of their bodies. For example, the best swimmers have a streamlined shape that provides a flow pattern without boundary layer separation [1-3]. This delays the laminar-to-turbulent transition and reduces drag. The estimates in [4] show that the critical Reynolds number can be quite high for special shaped unseparated bodies of revolution, similar to the bodies of aquatic animals. This fact allowed us to conclude that the shape itself can provide low drag inherent in laminar flow [4], and very simply solve the well-known Gray paradox concerning the dolphin swimming [5-9].

The fastest fish, e.g., sailfish Istiophorus platypterus Show and Nodder, swordfish Xiphias gladius L., black marlin Makaira indica Cuv et Val., etc. [1,10,11], have another feature of their shape - a very sharp nose - rostrum, the purpose of which remains unclear. Popular belief that the rostrum is used by these predators to pierce their prey is often disputed [12]. In this study, we will analyze the hydrodynamic aspects of the rostrum presence and the possible use of similar hulls for supercavitating underwater vehicles and fast penetration into water. We will illustrate that shapes with the very sharp nose could be useful for hypersonic motion in order to eliminate overheating of the vehicle fuselage.

\section{Materials and methods}

\section{Simulation of steady axisymmetric flows by sources and sinks}

We will use the standard expressions for Reynolds and Mach numbers: 


$$
\operatorname{Re}_{L}=\frac{U_{\infty} L}{v}, \operatorname{Re}_{V}=\frac{U_{\infty} V^{1 / 3}}{v}, M=\frac{U_{\infty}}{a_{\infty}},
$$

where $L$ and $V$ are the body length and volume; $v$ is the kinematic viscosity; $U_{\infty}$ and $a_{\infty}$ are the flow and sound speeds at infinity. We assume the Reynolds numbers (first two equations (1)) to be large enough (for example, $\operatorname{Re}_{L}>50000$ ) such that the boundary-layer thickness can be neglected and fluid outside a body and a thin layer on its surface can be treated as ideal.

If $M<<1$, the potential flow of a source with intensity $Q_{i}$ located at the point $\left(\xi_{i}, 0\right)$ can be expressed by the streamline function [13]:

$$
\Psi_{i}(x, r)=0.5 r^{2}-\frac{Q_{i}\left(x-\xi_{i}\right)}{4 \pi \sqrt{\left(x-\xi_{i}\right)^{2}+r^{2}}}+C_{i},
$$

where $x, r$ are cylindrical coordinates; $C_{i}$ is a constant value. Then the dimensionless (based on $U_{\infty}$ ) components of the flow velocity $v_{x}=v_{i x}$ and $v_{r}=v_{i r}$ can be calculated from (2) as follows:

$$
\begin{aligned}
& v_{i x}=\frac{1}{r} \frac{\partial \Psi_{i}}{\partial r}=1+\frac{Q_{i}\left(x-\xi_{i}\right)}{4 \pi\left[\left(x-\xi_{i}\right)^{2}+r^{2}\right]^{3 / 2}}, \\
& v_{i r}=-\frac{1}{r} \frac{\partial \Psi_{i}}{\partial x}=\frac{r Q_{i}}{4 \pi\left[\left(x-\xi_{i}\right)^{2}+r^{2}\right]^{3 / 2}} .
\end{aligned}
$$

The rigid body shape $R(x)$ can be obtained from (2) with the use of simple equation [16]:

$$
\Psi_{i}(x, R(x))=0 .
$$

The nose of the body is located at the axis of symmetry $r=0$ and its coordinate $x_{n}$ can be calculated with the use of (3) as follows:

$$
x_{n}=-\sqrt{\frac{Q_{i}}{4 \pi}} .
$$

The velocity at this point is equal to zero (see (3), (4)); the pressure $p$ and pressure coefficient

$$
c_{p}=\frac{2\left[p-p_{\infty}\right]}{\rho_{\infty} U_{\infty}^{2}}=1-v_{x}{ }^{2}(x, R(x))-v_{r}{ }^{2}(x, R(x))
$$

reach their maximum values $\left(p_{\infty}\right.$ and $\rho_{\infty}$ are the pressure and the fluid density in the ambient flow). Thus the nose of the body has a stagnation point with the maximum pressure.

With the use of $n$ sources and thinks $\left(Q_{i}<0\right)$ located at the axis of symmetry, different bodies of revolution can be simulated by adding corresponding functions $\Psi_{i}, v_{i x}$ and $v_{i r}$ :

$$
\Psi=\sum_{i=1}^{n} \Psi_{i}, \quad v_{x}=\sum_{i=1}^{n} v_{i x}, \quad v_{r}=\sum_{i=1}^{n} v_{i r} .
$$

Similar to (5), their radii $R(x)$ may be calculated from

$$
\sum_{i=1}^{n} \Psi_{i}(x, R(x))=0
$$

If the total intensity of sources if equal to the total intensity of sinks $\left(\sum_{i=1}^{n} Q_{i}=0\right)$, it is possible to obtain a closed body of revolution. Otherwise the body is unclosed (see examples in [3, 4]). Equations (8) and (9) can be treated as an exact solution of Euler equations for inviscid incompressible fluid.

\section{Slender body theories}

The method presented in previous Subsection allows calculating the flow around a body of a given shape or with a given pressure distribution on its surface, provided the use of appropriate algorithms for selecting the distribution of intensities of sources and sinks (in some cases also dipoles or other singularities are necessary, see, e.g., [14]). If the body of revolution is elongated $(L / D>>1$, $D$ is the maximum diameter, see Fig. 1) and moves along the axis of symmetry, it is possible to use slender body theories which allow calculating the sources distribution $q(x)$ with the use of $R(x)$ at different Mach numbers.

In particular, instead of (8) we can use the following expression for the streamline function [13]:

$$
\begin{gathered}
\Psi(x, r)=0.5 r^{2}-\frac{1}{4 \pi} \int_{0}^{\eta} \frac{(x-\xi) q(\xi) d \xi}{\sqrt{(x-\xi)^{2}-w^{2} r^{2}}}+C_{i}, \\
\omega=\sqrt{\left|M_{\infty}^{2}-1\right|}, \eta=\left\{\begin{array}{l}
1, M_{\infty}<1, \\
x-w r, M_{\infty}>1,
\end{array}\right. \\
q(x)=\left\{\begin{array}{l}
\pi \frac{d R^{2}}{d x}, M_{\infty}<1, \\
2 \pi \frac{d R^{2}}{d x}, M_{\infty}>1 .
\end{array}\right.
\end{gathered}
$$

Here we use dimensionless coordinates based on the body length $L$. The velocity components and the pressure coefficient can be obtained from (10) with the use (3), (4) and (7). In particular, for pressure coefficient the following formula can be used [13]: 


$$
c_{p} \approx-2 v_{x}=\int_{0}^{\eta} \frac{d^{2} R^{2}(\xi)}{d \xi^{2}} \frac{d \xi}{\sqrt{(x-\xi)^{2}+\left(1-M_{\infty}^{2}\right) r^{2}}}
$$

The following formulas:

$$
\begin{gathered}
c_{T}=\frac{2 k R\left(T-T_{\infty}\right)}{(k-1) U_{\infty}^{2}}=1-\left(v_{x}^{2}+v_{r}^{2}\right) \approx-2 v_{x} \approx c_{p}, \\
R_{g}=\frac{848 g}{\mu} \frac{m^{2}}{s^{2} K}, g=9.81 \mathrm{~m} / \mathrm{s}^{2}, \\
\mu=28.96, k=1.4
\end{gathered}
$$

can be used to calculate the temperature coefficient for supersonic flows in air, [13]. Here $T$ and $T_{\infty}$ are temperatures (local and in the ambient flow respectively), $R_{g}$ is the gas constant.

Some approximate formulas relate the local pressure on the slender body surface with its local radius $[15,16]$ :

$$
c_{p}(x)=-\ln \varepsilon \frac{d^{2} R^{2}}{d x^{2}}+O\left(\varepsilon^{2}\right), \varepsilon=\frac{D}{2 L} .
$$

It was shown in [16], that equation (14) is valid for both sub- and supersonic flows.

$$
\begin{aligned}
& \text { If } \\
& \begin{array}{c}
Q(x)=\int_{0}^{x} q(\xi) d \xi ; \quad Q_{i}=Q\left(\xi_{i}+h / 2\right)-Q\left(\xi_{i}-h / 2\right) ; \\
\xi_{i}=i h-h / 2, i=1,2,3, \ldots, n ; \quad h=1 / n,
\end{array}
\end{aligned}
$$

the integral in formula (10) can be replaced by sums similar to (8). In particular, at $M=0$ such replacement yields an exact solution of Euler equations coinciding with (8), (9). In our MATLAB codes we have used sums instead of integral (10). Examples of calculations are shown in Fig. 1 for two different sources intensities distributions:

$$
\begin{aligned}
& q_{1}(x)=\left\{\begin{array}{l}
a x^{2}+b x, 0 \leq x \leq x_{*}, \\
a_{1}(x-1)^{2}, x_{*} \leq x \leq 1,
\end{array}\right. \\
& q_{2}(x)=\left\{\begin{array}{l}
c x^{3}+d x^{4}, 0 \leq x \leq x_{*}, \\
a_{1}(x-1)^{2}, x_{*} \leq x \leq 1,
\end{array}\right.
\end{aligned}
$$

where $a, b, c, d, a_{1}$ and $x_{*}$ are constant parameters.

Fig. 1 illustrates that distribution (16) yields concave nose of the body and much smaller values of pressure on it. The pressure distributions corresponding to the exact solution and the slender body theory are rather close (except for the midline of the body). It follows from (3) and (10) that:

$$
v_{x} \sim q(x) / x^{2}
$$

near the point $(0,0)$. It follows from (15) and (17) that axial velocity is still infinite (like in the case of single source (3) at the point $\left.\left(\xi_{i}, 0\right)\right)$. It means that corresponding body has a stagnation point at some negative value of $x$ (not shown in Fig. 1). For comparison, distribution (16) yields a small value of $v_{x}$ in (17) and the absence of the stagnation point on corresponding body with the concave nose (see solid black line in Fig. 1).

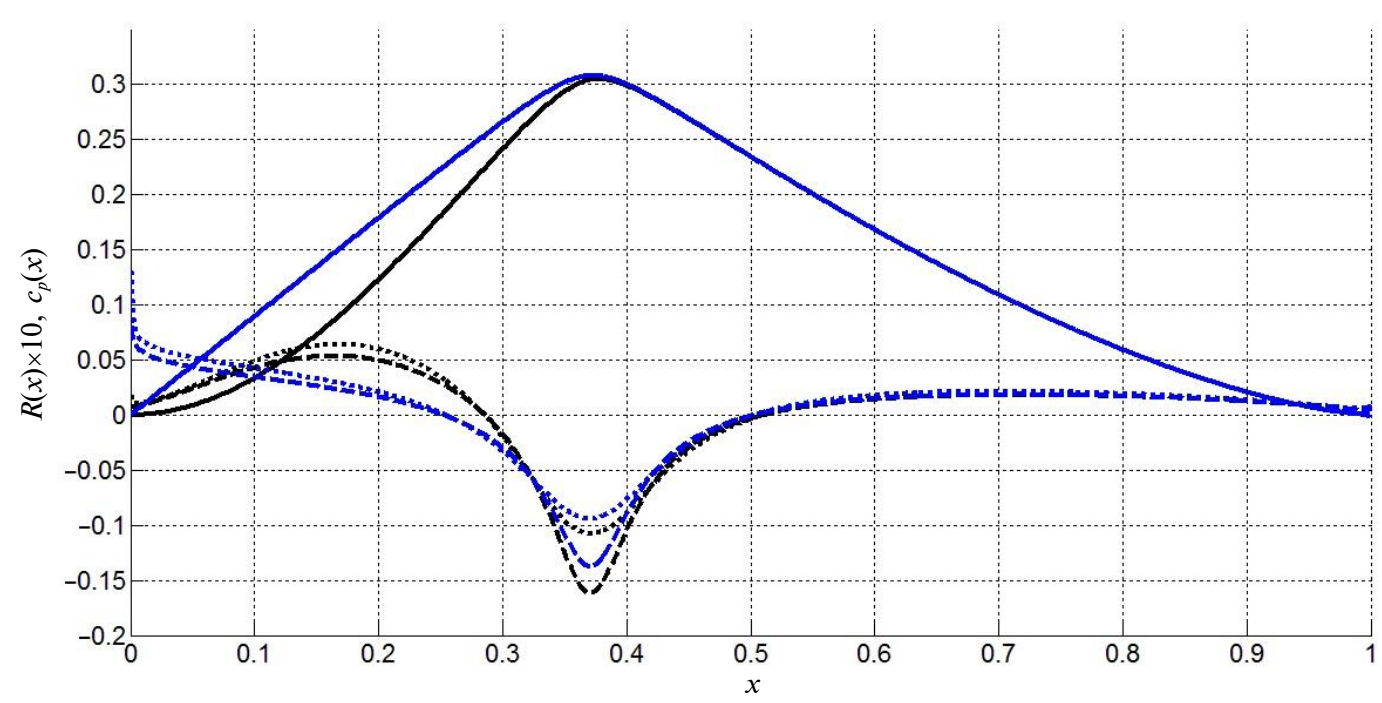

Figure 1: Comparison of exact solutions and the slender body theory for two different shapes. Blue lines correspond to sources distribution (15), black lines - distribution (16). Exact solution (8), (9) was used to calculate body shapes $(R(x) \times 10$, solid lines); dashed lines show corresponding pressure coefficient (7); dotted lines illustrate the application of the linear theory to calculate the pressure coefficient (12) with the use of exact solution for the body radius 


\section{Results}

The maximal swimming speed of the fastest fish (e.g., sailfish Istiophorus platypterus Show and Nodder, swordfish Xiphias gladius L., black marlin Makaira indica Cuv et Val.) is around $30 \mathrm{~m} / \mathrm{s}[1,10$, 11]. At such high velocities, the pressure at a stagnation point exceeds the ambient one by $4.5 \mathrm{~atm}$. (see eq. (7)). Probably, rostrums allow these animals to remove stagnation points and high pressures on the body surface. To support this hypothesis, a series of calculations has been carried out with the use of exact solution (8), (9) and the sources/sinks intensity distribution (16). The results are shown in Figs. 2 and 3.

Shapes with sharp concave rostrums and without stagnation points were obtained. The values of the parameters $a, b, c, d, a_{1}$ and $x_{*}$ in (16) were chosen to obtain a rather good similarity with the trunks of sailfish, black marlin and swordfish. To investigate what happens when the body nose is not concave, the distribution (15) was used without changing the values of parameters $a_{1}$ and $x_{*}$. The results of similar calculations can be found also in [4]. The corresponding body radius (red dotted line) and the pressure distribution (red dashed line) are also shown in Figs. 2 and 3. It can be seen that rather small changes of shape (compare green solid line and red dotted one in Fig. 2) cause significant difference in pressure distributions (compare green and red dashed lines). In particular, there is a stagnation point on the shape with convex nose (red dotted line) located very close to the point $(0,0)$, which is not shown in Figs. 2 and 3.

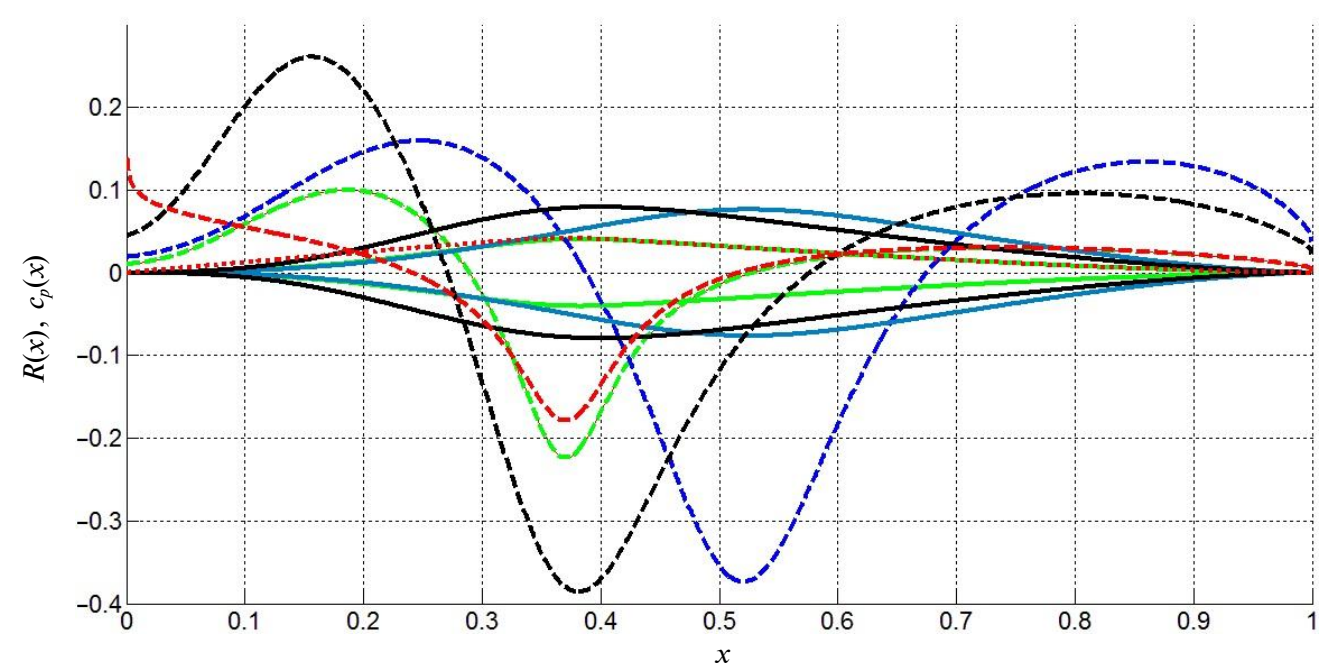

Figure 2: Axisymmetric shapes with rostrums (solid lines) similar to sailfish (green), swordfish (blue) and black marlin (black). Dashed lines correspond to pressure distributions. Red lines show the shape (dotted) without concave nose and corresponding pressure distribution (dashed) calculated in [4] with the use of distribution (15)

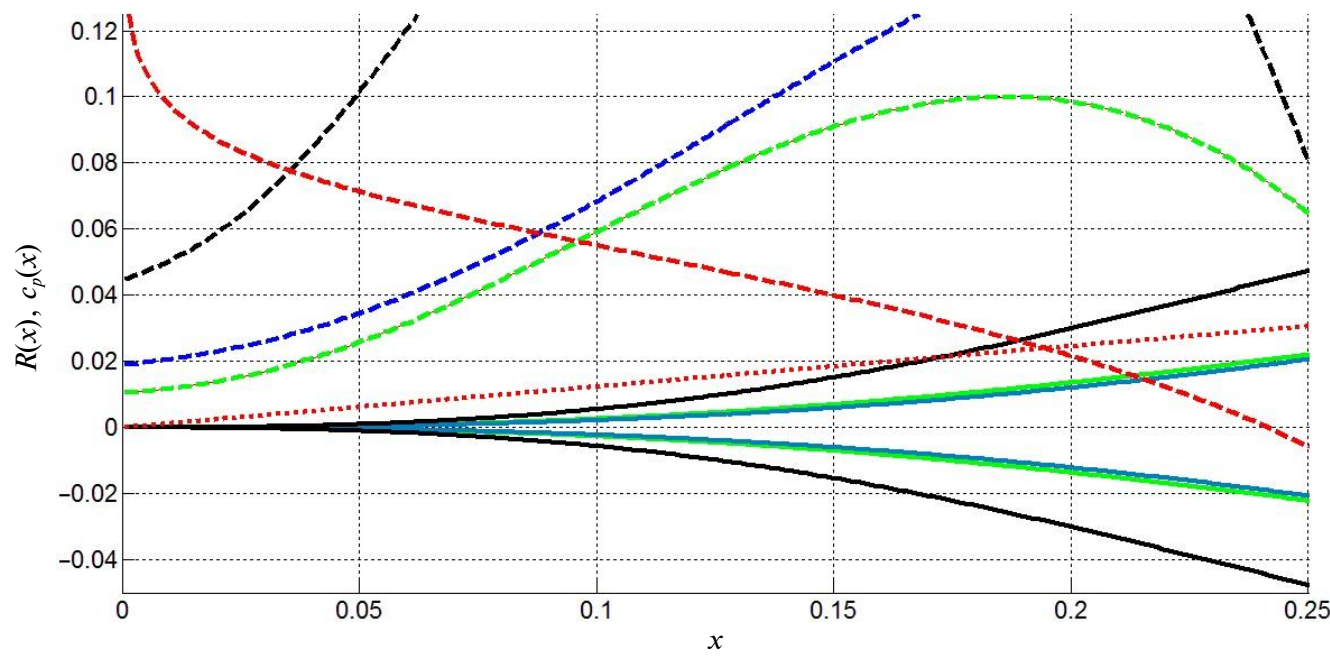

Figure 3: A zoomed part of Fig. 2 


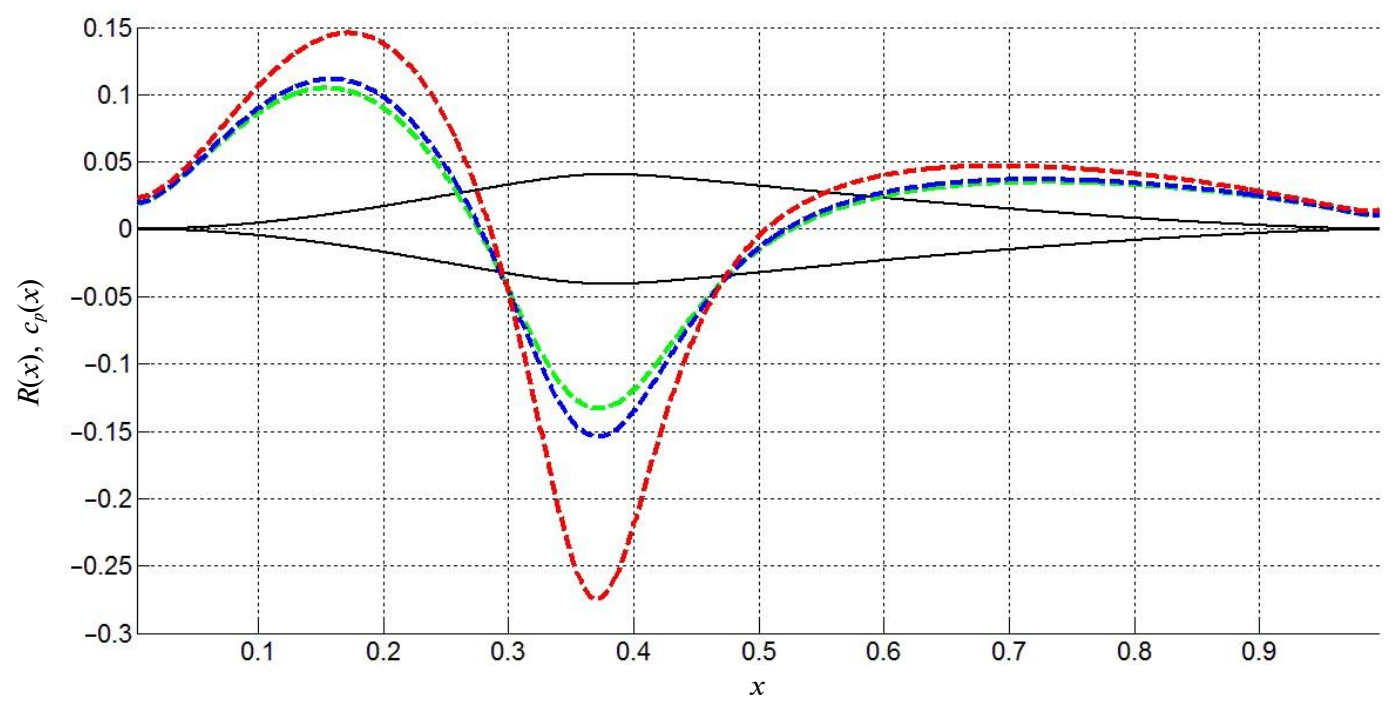

Figure 4: Shape of axisymmertic body with the rostrum (black lines) calculated with the use of exact solution (8), (9) at $M=0$. Dashed lines correspond to the pressure distributions calculated with the use of (12). Green, blue and red lines correspond to $M=0$; 0.5 and 0.9 respectively

The absence of a stagnation point is very important at high velocities when the corresponding pressure increases drastically $\left(p \sim U_{\infty}^{2}\right.$ according to equation (7)) and the fluid compressibility has to be taken into account. To simulate the influence of Mach number, a new series of calculations has been performed with the use of (8), (9), (12) and the sources/sinks intensity distribution (16). At $M>0$ this solution in no more exact, but it accuracy can be rather good as Fig. 1 demonstrates. The results are shown in Fig. 4. The body shape (black lines) was calculated with the use of exact solution at $M=0$. The pressure distributions for $M=0,0.5$ and 0.9 were calculated with the use of approximate formula (12) (green, blue and red lines respectively). It can be seen that the body with a sharp concave rostrum can ensure small values of the pressure coefficient and absence of the stagnation point on its surface in a subsonic flow.

\section{Discussion}

\section{Drag on bodies of revolution with rostrum}

The absence of the stagnation point does not remove the question of the hydrodynamic drag on bodies with a rostrum. At small Mach numbers the minimum possible value of the drag can be achieved by eliminating the boundary-layer separation. In this case, not only the pressure drag decreases, but also the frictional one due to the delay of the laminar-to-turbulent transition [4]. On the bodies of revolution with the rostrum shown in Figs. 1-4, the pressure increases on their noses (in comparison with the bodies without rostrum shown in Figs. 1-3, calculated and tested in [3, 4, 17-19]). These positive pressure gradients can cause separation, the presence or absence of which requires further research. But it is worth noting that experiments with rigid bodies similar to the body shape of sailfish and swordfish revealed an attached flow pattern [1]. Unfortunately, the book [1] does not specify in what way the lack of the boundary-layer separation was proved.

If there is no separation on the surface of the body with the rostrum, then its drag $X$ can be estimated by the formula [4]:

$$
C_{V}=\frac{2 X}{\rho_{\infty} U_{\infty}^{2} V^{2 / 3}}=\frac{4.7}{\sqrt{\operatorname{Re}_{V}}}
$$

for Reynolds numbers less than the critical value [4]:

$$
\operatorname{Re}_{L}^{*}=\frac{59558 \pi L^{3}}{V} \text {. }
$$

It is seen from (18) that the value of drag does not depend on the shape and taking into account also (1) we can obtain: $X \sim U_{\infty}^{3 / 2} V^{1 / 2}$ (similar to other slender bodies of revolution without boundary-layer separation [4]).

The maximal speed $U_{\max }$ (in $\mathrm{m} / \mathrm{s}$ ) of an animal or a vehicle providing the laminar attached flow pattern was estimated in [4] as follows:

$$
U_{\text {max }} \approx 28.6 L^{7 / 9} .
$$


The body (hull) length in (19) must be taken in meters. The ratio $U_{\max } / L^{7 / 9}$ calculated in [4] is 13-20.8 for sailfish, $11.5-15.1$ for swordfish and 8.4-11.8 for black marlin. These values approach the maximal one (see (19)) and are higher or comparable than for some other good swimmers which have no rostrsharks, dolphins, tunas). The $U_{\max } / L^{7 / 9}$ ratios for torpedoes Mark 48 and Spearfish (having no rostrum) are 7.23 and 9.17 respectively [4]. Thus, we can conclude that the presence of rostrum does not increase the drag.

\section{Supercavitating bodies of revolution with con- cave cavitatiors}

At high speed motion in water, the local pressures and the cavitation number

$$
\sigma=\frac{2\left(p_{\infty}-p\right)}{\rho_{\infty} U_{\infty}^{2}}=-c_{p} \approx \frac{2 g\left(h_{m}+10\right)}{U^{2}} .
$$

decrease and cavitation occurs [20-23]. In formula (20) we have neglected the pressure inside the cavity in comparison with the atmospheric pressure, corresponding to the water column of $10 \mathrm{~m}$; $h_{m}$ is the depth of steady motion in meters. Nevertheless, pressures at the stagnation points can be very high according to the formula (7). E.g., at the nose of a slender cone entering the water at speed $1000 \mathrm{~m} / \mathrm{s}$, the local pressure can reach $5000 \mathrm{~atm}$. and can cause the destruction of the entering body.

To avoid this huge pressure increase, the special shapes without stagnation points can be used. In particular, special shaped concave cavitators (parts of the hulls wetted by water) were proposed in [24]:

$$
\tilde{R}(\tilde{x})=b_{1} \tilde{x}^{2}+\beta \tilde{x}+1, \quad \tilde{x} \leq 0 .
$$

Here and further in this Subsection, all dimensionless lengths (marked with a "wave") are based on the value of the cavitator radius $R_{0}$ at the point of cavity separation $\tilde{x}=0$. The conical cavitator corresponds to $b_{1}=0$, and the parameter $\beta$ is equal to the derivative of the radius of the cavitator at $\tilde{x}=0$. At $\beta=0.1 ; b_{1}=0.0025$, eqs. (11) and (21) allow obtaining the sources distribution (16) with $d=0$. It means that corresponding concave cavitator has no stagnation point (see (17)).

The friction drag can be diminished, when some part of the hull is located inside the cavity to avoid a contact with the water flow. To calculate the cavity shape, eq. (14) can be integrated with the use of the conditions of continuity of the radius and its derivative at $\tilde{x}=0$ :

$$
\tilde{R}^{2}(\tilde{x})=\frac{\sigma \tilde{x}^{2}}{2 \ln \beta}+2 \beta \tilde{x}+1, \quad \tilde{x} \geq 0 .
$$

Here we use the condition $\varepsilon=\beta$. The accuracy of the first approximation equation (22) can be increased with the use of next approximations which are dependent on the Mach number [25].

The examples of cavitators (eq. (21)), cavities (eq. (22)) and parts of the hulls located inside the corresponding cavities at $\varepsilon=\beta=0.1$ are shown in Fig. 5. Green and black lines represent concave cavitators, but only green one (corresponding $\left.b_{1}=0.0025\right)$ has no stagnation point. For comparison the conical cavitator is shown by the red line. Each of these 3 cavitators can be combined with the parts of the hull located inside the corresponding cavities (blue, magenta and brown lines).

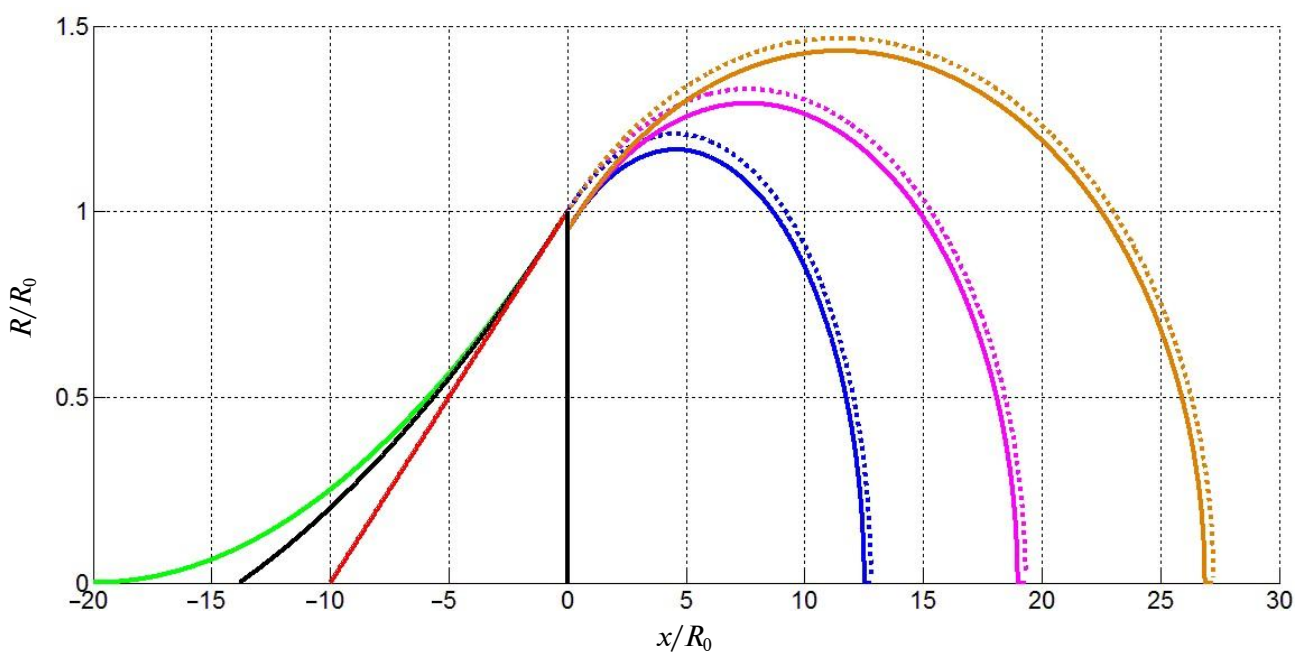

Figure 5: Shapes of axisymmertric cavitators, cavities and parts of the hulls located inside the cavities at $\varepsilon=\beta=0.1$. Green, black and red lines represent the cavitator radii at $b_{1}=0.0025 ; 0.002$ and 0 respectively. Blue, magenta and brown lines show the cavity shapes (dotted) and shapes of the hulls (solid) located in the corresponding cavities at $\sigma=0.1,0.06$ and 0.04 respectively 
The pressure drag $X_{p}$ on cavitator and corresponding volumetric drag coefficient $C_{V p}$

$$
C_{V p}=\frac{2 X_{p}}{\rho_{\infty} U_{\infty}^{2} V^{2 / 3}}
$$

was calculated in [24] with the use of exact solution (similar to proposed in [16]) based on (21), (22) and corresponding sources/sinks distributions (11) at $M_{\infty}=0$. The volume of the hull $V$ was assumed to be equal to the total volume of cavitator and the corresponding cavity (the volume the gap between the hull and the cavity surface was neglected). The results of calculations demonstrated that the pressure drag coefficient is minimal for the concave cavitator without stagnation point $\left(b_{1}=0.0025\right.$ [24]). The friction drag on concave cavitator could be larger in comparison with the conical one. But for concave cavitator with $b_{1}=0.0025$, the surfaceto-volume ratio is only $11 \%$ higher then for conical one $\left(b_{1}=0\right)$. Therefore, at fixed volumes, the bodies of revolution without stagnation points remove high pressures on their surface without increasing the drag.

\section{Hypersonic bodies of revolution with rostrums}

For a vehicle moving in the air at high Mach numbers, it is critical to reduce the heating of its surface (see, e.g., [26-31]). Many different approaches have been proposed to optimize the shape of hypersonic hulls [32-39], but the von Karman ogive [40] remains the most common shape of the axisymmetric hypersonic forebody [41]. Even nonblunt conical noses proposed in $[34,41]$ cause a stagnation point and very high temperatures. According to (13) the local temperature of air can be estimated as:

$$
T=T_{\infty}+\frac{(k-1) U_{\infty}^{2}}{2 k R} \approx T_{\infty}+4.97 \cdot 10^{-4} U_{\infty}^{2}
$$

in the vicinity of the stagnation point. The velocity $U_{\infty}$ in (23) must be taken in $\mathrm{m} / \mathrm{s}$. For example, at $U_{\infty}=3000 \mathrm{~m} / \mathrm{s}$, the local temperature exceeds the ambient one by $4476 \mathrm{~K}$.

If the shape of the body provides a flow without the stagnation point, the heating of its nose surface can be significantly reduced. The results of calculations are shown in Fig. 6 for different values of the Mach number. Since the pressure and temperature coefficient are very close for slender bodies (see (13)), one curve represent the distribution of the pressure and the temperature versus longitudinal coordinate $x / L$. At $M_{\infty}=0$ the body shape (solid black line) and pressure distribution (dashed black line) were calculated with the use of exact solution (8), (9) and the sources/sinks distribution (16). Pressure and temperature coefficients on the surface of this body were calculated with the use of (12) and (13) at $M_{\infty}=3 ; 5 ; 10$ and 20 (dashed blue, magenta, brown and green lines respectively).

A significant pressure drag $X_{p}$ occurs at supersonic speeds. The corresponding drag coefficient was calculated for the slender body of revolution presented in Fig. 6. The results are $C_{V p}=0.0077$; $0.0053 ; 0.0019$ and $5.35 \cdot 10^{-5}$ at $M_{\infty}=3 ; 5 ; 10$ and 20 respectively. These values can be compared

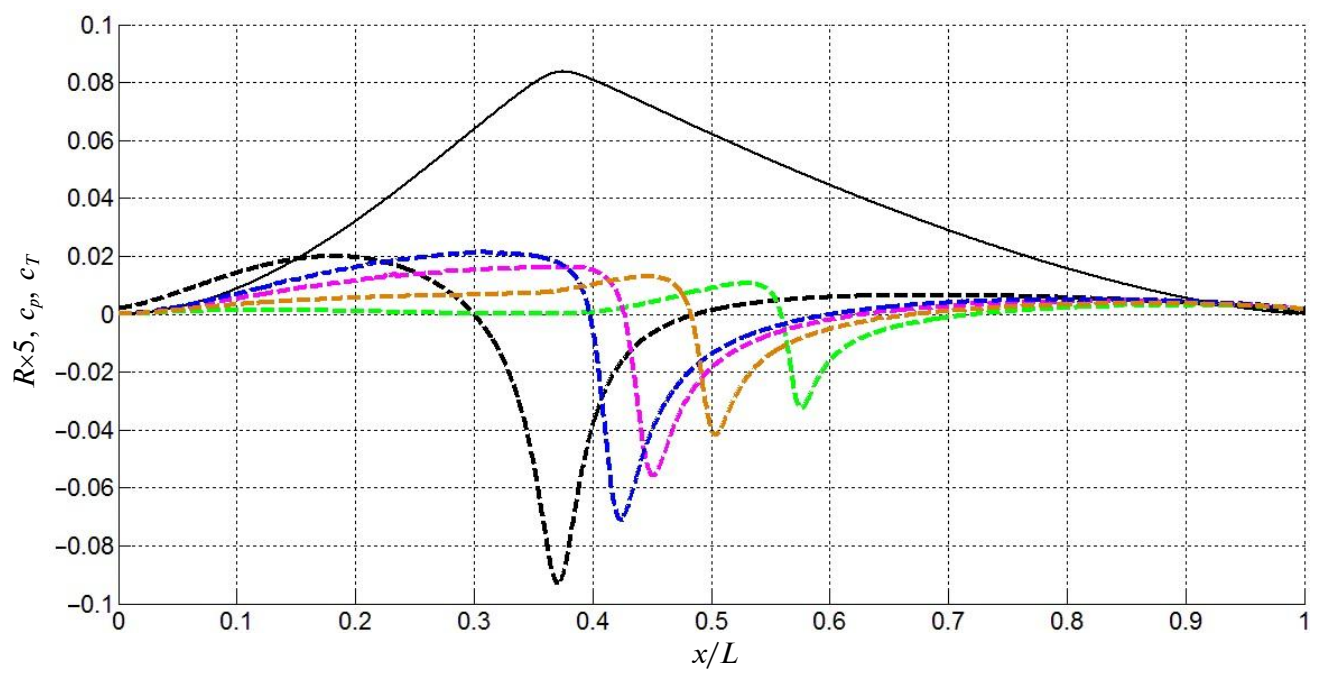

Figure 6: Shape of the slender body of revolution with the rostrum and pressure/temperature coefficients distributions at different values of Mach number. Black lines represent the body radius $\left(R(x / L) \times 5\right.$, solid) and $c_{p}(x / L)$ (dashed) calculated with the use of exact solution (8), (9) and the sources/sinks distribution (16). Dashed blue, magenta, brown and green lines show the pressure and temperature coefficients on the surface of this body calculated with the use of (12) and (13) at $M_{\infty}=3 ; 5 ; 10$ and 20 respectively 
with the $C_{V p}$ value for Sears-Haack body (with blunt leading and trailing edges) which ensures the least pressure drag ant fixed volume and length [40]:

$$
C_{V p}=\frac{128 V^{4 / 3}}{\pi L^{4}} \text {. }
$$

Putting into (24) the value $V / L^{3}=2.365 \cdot 10^{-4}$ calculated for the body shown in Fig. 6, we obtain $C_{V p} \approx 5.96 \cdot 10^{-4}$. This figure is much smaller than listed below $C_{V p}$ values for the body with rostrum (shown in Fig. 6), but at $M=20$ this body has much lower pressure drag coefficient. This fact requires further research.

Fig. 6 shows that the temperature coefficient on the entire body surface does not exceed 0.02 . This means that special body shapes with rostrums can reduce the maximum temperature on their surface by more than 50 times. In particular, at a speed of $3000 \mathrm{~m} / \mathrm{s}$, this maximum temperature exceeds the ambient one by no more than $90 \mathrm{~K}$ on the entire surface of the body shown in Fig. 6.

\section{Conclusions}

Bodies of revolution with a rostrum similar to trunks of the fastest fish (sailfish, swordfish and black marlin) were calculated with the use of exact solution of Euler equations. The corresponding flow patterns have no stagnation point. This fact allows diminishing the maximum pressure on the surface. Similar shapes with the sharp concave nose could be recommended for cavitators in order to reduce significant local loads on the high-speed supercavitating bodies of revolution without loses in volumetric drag coefficient. Proposed axisymmetric bodies also demonstrate significant reduces in air temperature on the surface at high Mach numbers.

\section{References}

[1] Aleyev YG. Nekton. The Hague: Dr. W. Junk; 1977. p. 167-255.

[2] Rohr J, Latz MI, Fallon S, Nauen JC, Hendricks E. Experimental approaches towards interpreting dolphin stimulated bioluminescence. J Exp Biol. 1998 May;201(9):1447-60.

[3] Nesteruk I, Brühl M, Möller T. Testing a special shaped body of revolution similar to dolphins trunk. KPI Sci News. 2018;2:44-53. DOI: 10.20535/1810-0546.2018.2.129140

[4] Nesteruk I. Maximal speed of underwater locomotion. Innov Biosyst Bioeng. 2019;3:152-67. DOI: 10.20535/ibb.2019.3.3.177976

[5] Gray J. Studies in animal locomotion VI. The propulsive powers of the dolphin. J Exp Biol. 1936;13:192-99.

[6] Fish FE, Rohr J. Review of dolphin hydrodynamics and swimming performance. San Diego: SPAWARS; 1999.

[7] Fish FE. The myth and reality of Gray's paradox: implication of dolphin drag reduction for technology. Bioinspir Biomim. 2006;1:R17-R25. DOI: 10.1088/1748-3182/1/2/r01

[8] Fish FE, Legac P, Williams TM, Wei T. Measurement of hydrodynamic force generation by swimming dolphins using bubble DPIV. J Exp Biol. 2014;217:252-60. DOI: 10.1242/jeb.087924

[9] Bale R, Hao M, Bhalla APS, Patel N, Patankar NA. Gray's paradox: A fluid mechanical perspective. Sci Rep. $2014 ; 4: 5904$. DOI: $10.1038 /$ srep05904

[10] Top 10: What are the fastest fish in the world? [Internet]. BBC Science Focus Magazine. 2020 [cited 2020 Sept 15]. Available from: https://www.sciencefocus.com/nature/top-10-what-are-the-fastest-fish-in-the-world/

[11] KNOWLEDGE G, Anwar S. Top 10 Fastest Fish in the World [Internet]. Jagranjosh.com. 2020 [cited 2020 Sept 15]. Available from: https://www.jagranjosh.com/general-knowledge/fastest-fish-in-the-world-1556626683-1

[12] Swordfish [Internet]. En.wikipedia.org. 2020 [cited 2020 Sept 15]. Available from: https://en.wikipedia.org/wiki/Swordfish

[13] Loitsyanskiy LG. Mechanics of liquids and gases. 6th ed. New York, Wallingford: Begell House; 1995. p. 323-34.

[14] Nesteruk I. Technology applications of the low drag shapes of aquatic animals. Biosci Bioeng. 2015;1(2):29-33.

[15] Cole JD. Perturbation methods in applied mathematics. Waltham, London: Blaisdell Pub. Co.; 1968.p. 180-96.

[16] Nesteruk I. Body forms of minimal drag. Dopovidi AN Ukr SSR Ser A. 1989;4:57-60.

[17] Lutz T, Wagner S. Drag reduction and shape optimization of airship bodies. J Aircraft. 1998;35(3):345-51. DOI: 10.2514/2.2313

[18] Goldschmied FR. Integrated hull design, boundary layer control and propulsion of submerged bodies: wind tunnel verification. In: Proceedings of the AIAA/SAE/ASME 18th Joint Propulsion Conference; 1982; Cleveland. Paper 82-1204. DOI: $10.2514 / 6.1982-1204$

[19] Hansen RJ, Hoyt JG. Laminar-to-turbulent transition on a body of revolution with an extended favorable pressure gradient forebody. J Fluids Eng. 1984;106:202-10. DOI: 10.1115/1.3243103

[20] Knapp RT, Daily JW, Hammitt FG. Cavitation. New York: McGraw Hill; 1970. 
[21] Logvinovich GV. Hydrodynamics of flows with free boundaries. Kyiv: Naukova Dumka; 1969.

[22] Franc JP, Michel JM. Fundamentals of cavitation. Dordrecht: Kluwer; 2004.

[23] Nesteruk I. Supercavitation. Advances and perspectives. Springer; 2012.

[24] Nesteruk I, Savchenko YM, Shepetyuk BD. Estimations of the cavitator curvature influence on pressure drag for a supercavitational axisymmetric circumfluence. Rep NAS Ukr. 2003;8:59-64.

[25] Nesteruk I. Calculation of steady axisymmetric supercavity flows of compressible fluid. Bull Kyiv Univer Ser Phys Math. 2003;4:109-18.

[26] Anderson JD. Hypersonic and high temperature gas dynamics. 2nd ed. Reston: AIAA Inc.; 2006.

[27] Han Q, Sun C, Tao Y, Li Z, Zhang Y, Chen Y. Thermal protection of a hypersonic vehicle by modulating stagnation-point heat flux. Aerospace Sci Technol. 2020;98:105673. DOI: 10.1016/j.ast.2019.105673

[28] Marley ChD. Thermal management in a scramjet-powered hypersonic cruise vehicle [dissertation on the internet]. Ann Arbor: University of Michigan; 2018. [cited 2020 Sept 15]. Available from: https://deepblue.lib.umich.edu/bitstream/handle/2027.42/144038/cmarley_1.pdf?sequence=1

[29] Falkiewicz NJ, Cesnik CES, Crowell AR, McNamara JJ. Reduced-order aerothermoelastic framework for hypersonic vehicle control simulation. AIAA J. 2011;49(8):1625-46. DOI: 10.2514/1.j050802

[30] Klock RJ, Cesnik CES. Nonlinear thermal reduced-order modelingfor hypersonic vehicles. AIAA J. 2017;55(7):2358-68. DOI: $10.2514 / 1 . j 055499$

[31] Brown RL, Das K, Cizmas PGA, Whitcomb JD. Numerical investigation of actively cooled structures in hypersonic flow. J Aircraft. 2014;51(5):1522-31. DOI: 10.2514/1.c032394

[32] Corda S, Anderson JD. Viscous optimized hypersonic waveriders designed from axisymmetric flow fields. In: Proceedings of 26th Aerospace Sciences Meeting; 1988; Reno. Paper 88-0369. DOI: 10.2514/6.1988-369

[33] Bowcutt KG, Anderson JD, Capriotti D. Viscous optimized hypersonic waveriders. In: Proceedings of 25th Aerospace Sciences Meeting; 1987; Reno. Paper 87-0272. DOI: 10.2514/6.1987-272

[34] Ding F, Shen CB, Liu J, Huang W. Influence of surface pressure distribution of basic flow field on shape and performance of waverider. Acta Astronaut. 2015;108:62-78. DOI: 10.1016/j.actaastro.2014.11.038

[35] He XZ, Le JL, Wu YC. Design of a curved cone derived waverider forebody. In: Proceedings of 16th AIAA/DLR/DGLR International Space Planes and Hypersonic Systems and Technologies Conference; 2009; Bremen. Paper 2009-7423. DOI: $10.2514 / 6.2009-7423$

[36] Jones JG, Moore KC, Pike J, Roe PL. A method for designing lifting configurations for high supersonic speeds, using axisymmetric flow fields. Ing Arch. 1968;37:56-72. DOI: 10.1007/BF00532683

[37] Lewis MJ. Application of waverider-based configurations to hypersonic vehicle design. In: Proceedings of 9th Applied Aerodynamics Conference; 1991; Baltimore. Paper 91-3304. DOI: 10.2514/6.1991-3304

[38] Rodriguez DL. Multidisciplinary optimization of a supersonic inlet using a Cartesian CFD method. In: Proceedings of 10th AIAA/ISSMO Multidisciplinary Analysis and Optimization Conference; 2004; Albany. AIAA Paper $2004-4492$. DOI: $10.2514 / 6.2004-4492$

[39] Takashima N, Lewis MJ. Navier-Stokes computation of a viscous optimized waverider. J Spacecr Rockets. 1994;31(3):383-91. DOI: $10.2514 / 3.26450$

[40] Nielsen JN. Missile aerodynamics. New York: McGraw-Hill Book Co., Inc.; 1960.

[41] Chen J, Fan X, Xiong B, Meng Z, Wang Y. Parameterization and optimization for the axisymmetric forebody of hypersonic vehicle. Acta Astronautica. 2020;167:239-44. DOI: 10.1016/j.actaastro.2019.10.047

\section{І.Г. Нестерук}

Інститут гідромеханіки НАН України, Київ, Україна

КПІ ім. Ігоря Сікорського, Київ, Україна

\section{ФОРМИ ТІЛА НАЙШВИДШИХ РИБ І ОПТИМАЛЬНІ СУПЕРКАВІТАЦІЙНІ ТА ГІПЕРЗВУКОВІ ТІЛА ОБЕРТАННЯ}

Проблематика. Найкращі плавці мають обтічну форму, яка забезпечує течію без відриву примежового шару і затримує ламінарно-турбулентний перехід. Сама їх форма може бути причиною малого опору та високої швидкості руху. Найшвидші риби, наприклад вітрильник, риба-меч, чорний марлін тощо, мають ще одну особливість своєї форми - дуже гострий ніс рострум, призначення якого залишається незрозумілим. Поширена думка, що ці хижаки використовують рострум для проколювання здобичі, часто піддається сумніву.

Мета. У цьому дослідженні ми аналізуємо гідродинамічні аспекти наявності роструму та можливе використання подібних корпусів для суперкавітуючих підводних апаратів і швидкого проникнення у воду. Ми ілюструємо, що форми з дуже гострим носом можуть бути корисними для гіперзвукових рухів, щоб виключити перегрів фюзеляжу транспортного засобу. 
Методика реалізації. Для моделювання розподілу тиску на тілах обертання з гострим носом використовуються відомі точні розв'язки рівнянь Ейлера для нестисливої рідини. Для моделювання суперкавітації та осесиметричної течії повітря за великих чисел Маха використовується теорія тонкого тіла.

Результати. Розраховано тіла обертання з рострумом, подібні до тулубів найшвидших риб (вітрильника, риби-меч, чорного марліна) та відповідні коефіцієнти тиску і температури. Запропоновані форми забезпечують відсутність точок гальмування потоку та високого тиску і температури на носику на до- та надзвукових швидкостях як у воді, так і в повітрі. Було оцінено опір таких тіл обертання для безвідривних, суперкавітаційних і надзвукових схем обтікання.

Висновки. Запропоновано метод розрахунку осесиметричних тіл без точок гальмування потоку на їхній поверхні. Ця особливість форми дає змогу зменшити максимальний тиск і температуру на носику без значного збільшення опору. Такі форми з гострим увігнутим носиком можна рекомендувати для високошвидкісних безвідривних і суперкавітаційних тіл обертання та для гіперзвукового руху.

Ключові слова: пересування водних тварин; тіла обертання; зменшення навантаження; зменшення опору; оптимізація фоорми; безвідривні форми; суперкавітація; гіперзвукові течії.

\section{И.Г. Нестерук}

Институт гидромеханики НАН Украины, Киев, Украина

КПИ им. Игоря Сикорского, Киев, Украина

\section{ФОРМЫ ТЕЛА САМЫХ БЫСТРЫХ РЫБ И ОПТИМАЛЬНЫЕ СУПЕРКАВИТАЦИОННЫЕ И ГИПЕРЗВУКОВЫЕ ТЕЛА ВРАЩЕНИЯ}

Проблематика. Лучшие пловцы имеют обтекаемую форму, которая обеспечивает течение без отрыва пограничного слоя и задерживает ламинарно-турбулентный переход. Сама их форма может быть причиной малого сопротивления и высокой скорости передвижения. Самые быстрые рыбы, например парусник, рыба-меч, черный марлин и т.д., имеют еще одну особенность фоормы - очень острый нос - рострум, назначение которого остается неясным. Распространенное мнение о том, что эти хищники используют рострум для прокалывания своей добычи, часто оспаривается.

Цель. В этом исследовании мы анализируем гидродинамические аспекты наличия рострума и возможное использование подобных корпусов для суперкавитирующих подводных аппаратов и быстрого проникновения в воду. Мы иллюстрируем, что формы с очень острым носом могут быть полезны для гиперзвукового движения, чтобы исключить перегрев фрюзеляжа транспортного средства.

Методика реализации. Для моделирования распределения давления на телах вращения с острым носом ми используем известные точные решения уравнений Эйлера для несжимаемой жидкости. Для моделирования суперкавитации и осесимметричных течений воздуха при высоких числах Маха используется теория тонкого тела.

Результаты. Рассчитаны тела вращения с рострумом, подобные туловищам самых быстрых рыб (парусника, рыбы-меч, черного марлина), и соответствующие коэффрициенты давления и температуры. Предложенные формы гарантируют отсутствие точки торможения потока и высокого давления и температуры на носике на до- и сверхзвуковых скоростях как в воде, так и в воздухе. Проведены оценки сопротивления таких тел вращения для безотрывных, суперкавитационных и сверхзвуковых схем обтекания.

Выводы. Предложена методика расчета осесимметричных тел без точек торможения на их поверхности. Эта особенность формы позволяет снизить максимальное давление и температуру на носике без значительного увеличения лобового сопротивления. Такие формы с острым вогнутым носиком могут быть рекомендованы для высокоскоростных безотрывных и суперкавитационных тел вращения, а также для гиперзвукового движения.

Ключевые слова: передвижение водных животных; тела вращения; снижение нагрузок; снижение сопротивления; оптимизация формы; безотрывные формы; суперкавитация; гиперзвуковые течения. 